\title{
'Robert Livermore', a Persian Walnut Cultivar with a Red Seedcoat
}

\author{
Gale McGranahan ${ }^{1}$ and Chuck Leslie \\ Department of Pomology, University of California, Davis. CA 95616
}

Additional index words. Juglans regia L., breeding, anthocyanidin

This new persian walnut (Juglans regia L.) cultivar 'Robert Livermore', tested as UC91-75-15, is distinguished by a red seedcoat (testa or pellicle) (Fig. 1). In all other respects it is typical of commercially available persian walnut (Juglans regia L.) cultivars.

\section{Origin}

'Robert Livermore' is derived from a controlled cross-pollination between UC86-11 and 'Howard', a cultivar released by the University of California in 1978 (Fig. 2). 'Howard' (Plant Pat. No. 4,388) has typical extra light or light kernels. UC86-11 is a germplasm introduction obtained as scionwood identified as RA1088 from the walnut collection of the Institut National de la Recherche Agronomique, Station de Recherches d'Arboriculture Fruitière, Bordeaux, France). On the introduction papers RA 1088 is described as "Juglans purpurea à cerneau rouge". Krussman (1984) describes a J. regia variety 'Purpurea' with dull red leaves and another variety 'Rubra' as having a red nutmeat and a blood-red epidermis. The parent, UC8611 , has a reddish brown seedcoat and a typical light cream-colored kernel. Both parents and offspring have the typical green leaves of $J$. regia. Thus neither the reddish parent nor the offspring fit those descriptions.

The cross made in 1991 resulted in 14 surviving progeny of which six had the red seedcoat and six had the typical light tan seedcoat and two have not yet produced flowers. Other crosses made with UC86-11 resulted in a progeny ratio of 106 red: $119 \tan , \chi^{2}=$ $0.75, p=0.39$. Although the red color in the progeny ranges from light pink to dark reddish brown, it appears that the presence of pigment coloration is inherited as a single dominant gene, $R$, present in the heterozygous condition in UC86-11.

\section{Description}

'Robert Livermore' was selected from among the progeny, all grown on University of California, Davis, field plots, because it was relatively precocious, blooming in the fourth year from germination. About $90 \%$ of the lateral buds are fruitful and estimated yield is

Received for publication 22 Oct. 2003. Accepted for publication10 Feb. 2004. We thank the Walnut Marketing Board for funding the walnut breeding program, and Robert Livermore for his support, curiosity, and enthusiasm for the unusual. This cultivar is dedicated to him.

${ }^{1}$ Corresponding author; e-mail ghmcgranahan@ucdavis. edu.

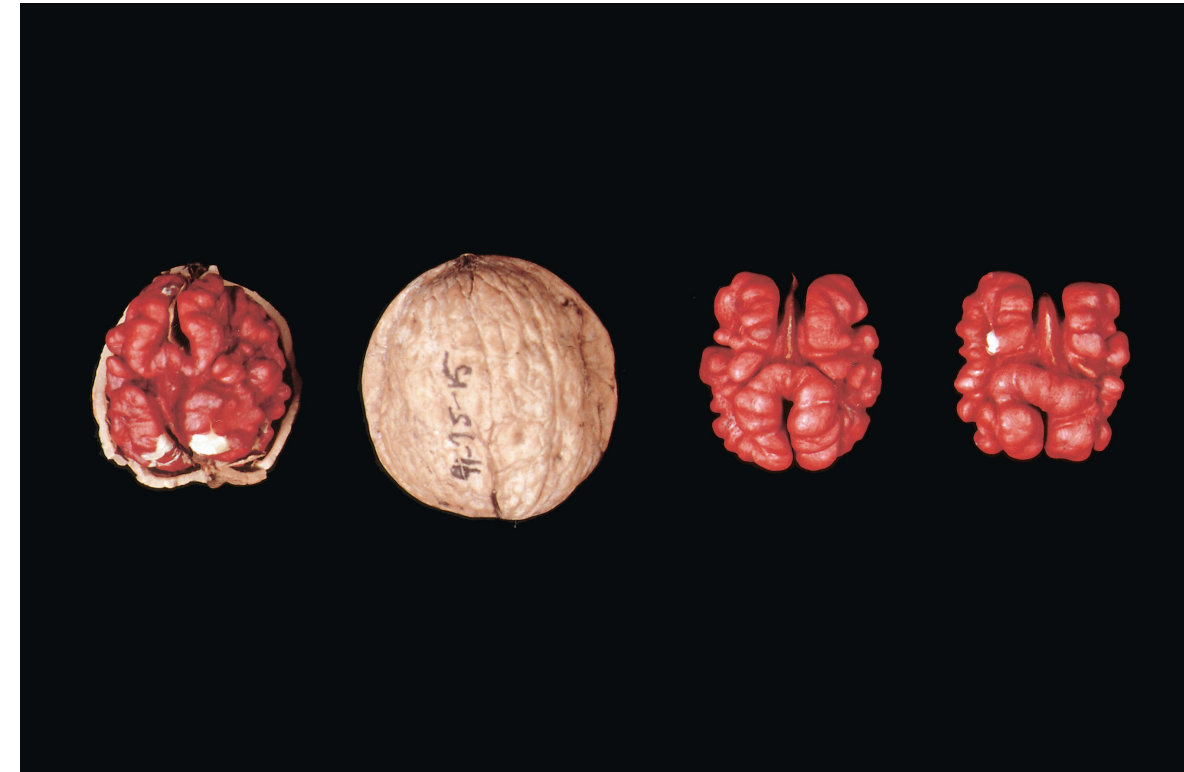

Fig.1. Walnut cultivar Robert Livermore (tested as UC91-75-15).

Fig. 2. Pedigree of 'Robert Livermore'.

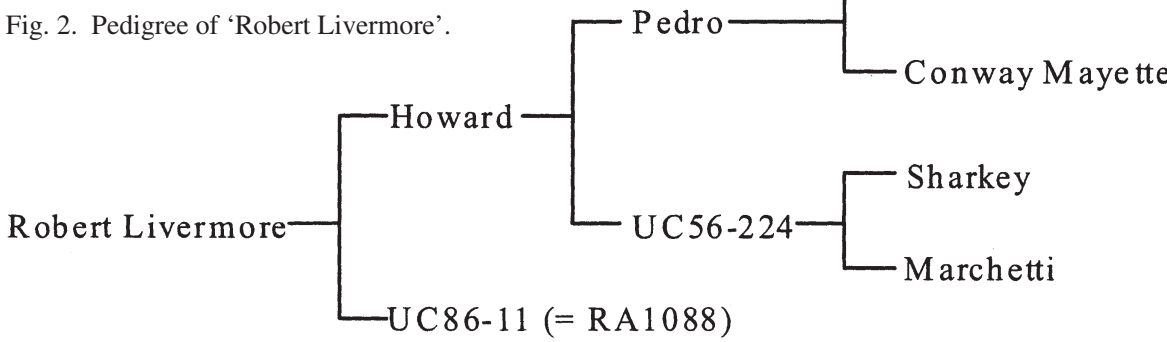

good but not outstanding. 'Robert Livermore' leafs out and blooms near 'Chandler' time and is ready to harvest about one week earlier. The pollen shedding period of 'Robert Livermore' overlapped the pistillate bloom in three out of four years. Other satisfactory pollenizers would be 'Tulare' and 'Cisco'.

The nut has a strong shell and a good seal. The shell is well-filled and the kernel is quite easy to extract. The kernel $(7.0 \mathrm{~g})$ makes up $50 \%$ of the total nut weight $(14.1 \mathrm{~g})$. These values are averages of seven years of data collection as described in Forde and McGranahan (1996). The seedcoat is a red, 39-11 to 39-14 on the Munsell scale (Munsell Color, Macbeth Color and Photometry Division, Baltimore, Md.) All the nuts produced have the same color red seedcoat because the seedcoat is maternal tissue. The color has been attributed to anthocyanidins (Bruce Campbell, personal communication). This cultivar is expected to serve niche markets.

\section{Availability}

'Robert Livermore' has been granted U.S. Plant Patent 12,264. The rights are assigned to the Regents of the University of California, Oakland, and nurseries are invited to apply for a license. Grafting wood is available from the authors.

\section{Literature Cited}

Forde, H.I. and G.H. McGranahan. 1996. Walnuts, p. 241-273. In: J. Janick and J.N. Moore (eds.). Fruit breeding. vol. 3. John Wiley and Sons, New York.

Krussmann, Gerd. 1984. Manual of Cultivated broad-leaved trees and shrubs. vol. 2. Timber Press. Portland, Ore. 